\title{
MENINGKATKAN HASIL BELAJAR PENDIDIKAN KEWARGANEGARAAN MELALUI MODEL SIKLUS BELAJAR PADA SISWA KELAS VIIA SMP NEGERI 3 BANTUL
}

\author{
Oleh: \\ Muh Fauzi Hartono \\ 1240101536 \\ Universitas Cokroaminoto Yogyakarta
}

\begin{abstract}
Abstrak
Penelitian ini bertujuan untuk meningkatkan hasil belajar PKn melalui Siklus Belajar siswa kelas VIIA SMP Negeri 3 Bantul. Jenis penelitian ini adalah penelitian tindakan kelas. Penelitian ini dilaksanakan dalam dua siklus. Subjek penelitian ini adalah siswa kelas VIIA SMP Negeri 3 Bantul. Instrumen penelitian yang digunakan berupa lembar observasi dan soal tes tertulis. Data yang diperoleh berupa tes hasil belajar sebagai data primer dan data observasi sebagai data skunder. Teknik analisis data yang digunakan adalah analisis kuantitatif dengan teknik persentase untuk hasil tes dan deskriptif kualitatif untuk observasi.

Hasil penelitian ini menunjukkan bahwa penggunaan Model Siklus Belajar Untuk meningkatkan hasil mata pelajaran Pendidikan kewarganegaran. Nilai rata-rata kelas meningkat, dari nilai pra tindakan menunjukkan nilai rata-rata siswa 64,97 dan siswa yang mendapat nilai tertinggi 93 dan terendah 41 dengan jumlah siswa 32 dan yang memenuhi nilai KKM 70 atau 56,25\%. Setelah dilakukan tindakan dengan model Siklus belajar di siklus I, hasil tes pada siklus I menunjukkan bahwa nilai rata-rata siswa meningkat menjadi 71,03 dan siswa yang mendapat nilai tertinggi 93 dan terendah 46 dengan persentase $61,8 \%$. Pada siklus II, nilai rata-rata siswa juga meningkat menjadi 75,80 dan siswa yang mendapat nilai yang memenuhi KKM $75 \%$.
\end{abstract}

Kata kunci: hasil belajar PKn, Siklus Belajar.

\section{PENDAHULUAN}

Pendidikan Kewarganegaraan (PKn) merupakan salah satu mata pelajaran yang menjadi bagian dari pendidikan ilmu sosial. Pengajaran Pendidikan Kewarganegaraan di Sekolah Menengah Pertama (SMP) ditujukan bagi pembinaan generasi penerus dengan berbagai macam tujuan.

Tujuan-tujuan Mata pelajaran Pendidikan Kewarganegaraan (Pkn) tersebut diantaranya agar peserta didik memiliki kemampuan yaitu berpikir secara kritis, rasional, dan kreatif dalam menanggapi isu kewarganegaraan; berpartisipasi secara aktif dan bertanggung jawab, bertindak secara cerdas dalam kegiatan bermasyarakat, berbangsa, dan bernegara, serta antikorupsi; berkembang secara positif dan demokratis untuk membentuk diri berdasarkan karakter-karakter masyarakat Indonesia agar dapat hidup bersama dengan bangsa-bangsa lainnya; dan berinteraksi dengan bangsa-bangsa lain dalam percaturan dunia secara langsung 
atau tidak langsung dengan memanfaatkan teknologi informasi dan komunikasi (Permendiknas No. 22 Tahun 2006).

Pembelajaran PKn juga bertujuan untuk meningkatkan kualitas manusia Indonesia yang berbudi luhur, berkepribadian, mandiri, maju, tangguh, profesional, bertanggung jawab, dan produktif serta sehat jasmani dan rohani. Melalui pendidikan Kewarganegaraan, rakyat Republik Indonesia diharapkan mampu memahami, menganalisa, dan menjawab masalahmasalah yang dihadapi oleh masyarakat, bangsa dan negaranya secara konsisten dan berkesinambungan dalam cita-cita dan tujuan nasional seperti yang digariskan dalam pembukaan UUD 1945.

Guru mempunyai peran dan fungsi yang penting dalam pengajaran. Guru yang mepunyai kompetensi yang tinggi akan mampu mendorong peserta didik meraih hasil belajar yang optimal. Pembelajaran juga harus berorentasi pada peserta didik, karena peserta didik merupakan komponen pokok dan subyek didik. Guru berfungsi sebagai pendorong, pembimbing, pengarah, pembina pertumbuhan dan perkembangan peserta didik, peningkatan hasil belajar akan tercapai apabila terjadi pembelajaran bermakna yaitu pembelajaran yang mampu melibatkan secara aktif peserta didik baik fisik, mental intelektual, dan emosional.

Pembelajaran Pendidikan Kewarganegaraan (PKn) di SMP Negeri 3 Bantul berdasarkan data nilai tahun pelajaran 2011/2012 semester 2 terdapat nilai rata-rata 63 dan materi yang memperoleh nilai terendah yaitu Perlindungan dan Penegakan Hak Asasi Manusia dengan nilai rata-rata 43. Nilai tersebut sangat jauh dari nilai Kriteria Ketuntasan Minimal (KKM) yang telah ditentukan di SMP Negeri 3 Bantul yaitu 65 .

Sampai saat ini harus diakui bahwa model pembelajaran yang mendominasi dalam kegiatan pembelajaran di kelas VIIA SMP Negeri 3 Bantul adalah pembelajaran yang berpusat pada guru (teacher centered instruction). Model pembelajaran ini cenderung membosankan dan mendorong siswa bersikap pasif sehingga pencapaian pemahaman materi yang disampaikan kurang maksimal. Pembelajaran dengan model seperti ini, tentu kurang memberikan kesempatan yang seluas-luasnya kepada anak untuk mengembangkan kemampuan dan kreativitasnya. Kegiatan belajar yang mampu mengembangkan kemampuan dan kreativitas anak secara maksimal adalah kegiatan belajar yang berpusat pada siswa. Di sini, guru berperan sebagai motivator dan fasilitator di dalamnya agar suasana kelas lebih hidup.

Berdasarkan kondisi tersebut, perlu dikembangkan suatu model pembelajaran yang tepat untuk pembelajaran Pendidikan Kewargangaraan (PKn). Salah satu model pembelajaran 
yang dapat diterapkan adalah model Siklus Belajar. Model Siklus Belajar memungkinkan siswa untuk berpartisipasi secara aktif dalam kegiatan belajar mengajar.

\section{LAJIAN TEORI}

\section{A. Pengertian Belajar}

Slameto (2003:2) menegaskan belajar adalah suatu proses usaha yang dilakukan seseorang untuk memperoleh suatu perubahan tingkah laku yang baru secara keseluruhan, sebagai hasil pengalamannya sendiri dalam interaksi dengan lingkungannya. Belajar itu merupakan perubahan tingkah laku atau penampilan dengan serangkaian kegiatan misalnya dengan membaca, mengamati, mendengarkan, meniru, dan lain sebagainya.

Menurut Gagne yang juga dikutip oleh Ngalim Purwanto (1991: 84) "Belajar terjadi apabila suatu situasi stimulus bersama dengan isi ingatan mempengaruhi siswa sedemikian sehingga perbuatannya berubah dari waktu sebelum ia mengalami situasi itu ke waktu sesudah ia mengalami situasi tadi. Sedang menurut Oemar Hamalik (2005:21) belajar adalah suatu bentuk pertumbuhan atau perubahan dari diri seseorang yang dinyatakan dalam caracara bertingkah laku yang baru berkat pengalaman dan latihan.

Dari pengertian-pengertian belajar di atas dapat disimpulkan bahwa belajar adalah suatu kegiatan yang dilakukan secara sengaja yang dapat menghasilkan perubahan tingkah laku pada seseorang.

\section{B. Pengertian Hasil Belajar}

Menurut Mulyono (2003: 37) hasil belajar adalah kemampuan yang diperoleh anak setelah melalui kegiatan belajar. Belajar itu sendiri merupakan suatu proses dari seseorang yang berusaha untuk memperoleh suatu bentuk perubahan perilaku yang relatif menetap. Dalam kegiatan yang terprogram dan terkontrol yang disebut kegiatan pembelajaran atau kegiatan intruksional, tujuan belajar telah ditetapkan lebih dahulu oleh guru. Anak yang berhasil dalam belajar ialah yang berhasil mencapai tujuan-tujuan pembelajaran atau tujuantujuan instruksional.

Slameto (2003: 54) menyatakan hasil belajar adalah perubahan yang terjadi dalam diri seseorang berlangsung secara berkesinambungan, tidak statis. Suatu perubahan yang terjadi akan menyebabkan perubahan berikutnya dan akan berguna bagi kehidupan maupun proses belajarnya.

Menurut Oemar Hamalik (2006:30) hasil belajar adalah bila seseorang telah belajar akan terjadi perubahan tingkah laku pada orang tersebut, misalnya dari tidak tahu menjadi tahu dan dari tidak mengerti menjadi mengerti. Tujuan pendidikan yang ingin dicapai dalam 
proses belajar mengajar dapat dikategorikan dalam tiga bidang, yaitu bidang kognitif, afektif dan psikomotorik.

Secara garis besar klasifikasi hasil belajar menurut Benjamin Bloom dan Krathwohl terbagi menjadi 3 ranah (Rusman, 2011: 177) yaitu:

1. Ranah Kognitif

Ranah kognitif yaitu menekankan pada aspek intelektual dan memiliki jenjang dari yang rendah sampai yang tinggi yaitu:

a. Pengetahuan/ingatan yang menitikberatkan pada aspek ingatan terhadap materi yang telah dipelajari mulai dari fakta sampai teori.

b. Pemahaman, yaitu langkah awal untuk dapat menjelaskan dan menguraikan sebuah konsep ataupun pengertian.

c. Aplikasi, yaitu kemampuan untuk menggunakan bahan yang telah dipelajari ke dalam situasi yang nyata, meliputi atuaran, metode, konsep, prinsip, hukum, dan teori.

d. Analisis, yaitu kemampuan dalam merinci bahan menjadi bagian-bagian supaya strukturnya mudah untuk dimengerti.

e. Sintesis, yaitu kemampuan mengkombinasikan bagian-bagian menjadi suatu keseluruhan baru yang menitikberatkan pada tingkah laku kreatif dengan cara memformulasikan pola dan struktur baru.

f. Evaluasi, yaitu kemampuan dalam mempertimbangkan nilai untuk maksud tertentu berdasarkan kriteria internal dan kriteria eksternal.

2. Ranah Afektif

Ranah afektif yaitu menekankan pada sikap, perasaan, emosi, dan karakteristik moral yang diperlukan untuk kehidupan di masyarakat. Ranah afektif memiliki 5 tingkatan dari yang rendah sampai pada yang tinggi, yaitu:

a. Penerimaan, misalnya kemampuan siswa untuk mau mendengarkan materi pembelajaran yang disampaikan oleh guru dan media pembelajaran dengan melibatkan perasaan, antusiasme, dan semangat belajar yang tinggi.

b. Jawaban atau reaksi, yaitu kemampuan siswa untuk memberikan timbal balik positif terhadap lingkungan dalam pembelajaran, misalnya: menanggapi, menyimak, bertanya, dan berempati.

c. Penilaian, yaitu penerimaan terhadap nilai-nilai yang ditanamkan dalam pembelajaran, membuat pertimbangan terhadap berbagai nilai untuk diyakini dan diaplikasikan.

d. Organisasi, yaitu kemampuan siswa dalam hal mengorganisasi suatu sistem nilai. 
e. Internalisasi yaitu pengembangan dari tingkat pengorganisasian terhadap representasi kehidupan secara luas.

3. Ranah Psikomotor

Ranah psikomotor yaitu ranah yang menekankan pada gerakan-gerakan fisik. Kecakapankecakapan fisik dapat berupa gerakan-gerakan atau keterampilan fisik, baik keterampilan fisik halus maupun kasar. Ranah ini sering berhubungan dengan mata pelajaran yang lebih menekankan pada gerakan-gerakan atau keterampilan fisik, seperti seni musik, lukis, pahat, dan mata pelajaran olahraga. Ada 6 aspek ranah psikomotor yaitu gerak reflek, ketrampilan gerakan dasar, kemampuan persetual, keharmonisan dan ketepatan, gerakan ketrampilan kompleks, serta gerakan ekspresif dan interpretatif.

Berdasarkan pendapat-pendapat di atas, maka pengertian hasil belajar dalam penelitian ini yaitu siswa diharapkan mampu mengetahui, memahami dan mengimplemantasikan teori serta konsep yang berkaitan dengan pendidikan PKn khususnya pada materi Perlindungan dan penegakan Hak Asasi Manusia (HAM) yang ditekankan pada ranah kognitif dengan penekanan pada aspek pengetahuan dan pemahaman. Derajat kemampuan yang diperoleh siswa diwujudkan dalam bentuk nilai hasil belajar PKn.

C. Faktor-faktor yang mempengaruhi hasil belajar

Slameto (2003: 54) membedakan belajar menjadi dua faktor, yaitu:

1. Faktor Intern

Faktor intern adalah faktor yang ada dalam diri individu yang sedang belajar. Faktor intern ini di bagi menjadi 3 faktor, yaitu:
a. Faktor Jasmani
b. Faktor Psikologi
c. Faktor kelelahan

\section{Faktor Ektern}

Faktor ekstern di bagi menjadi 3 faktor, yaitu:

a. Faktor Keluarga

b. Faktor Sekolah

c. Faktor Masyarakat

Berdasarkan uraian di atas dapat disimpulkan bahwa faktor-faktor yang mempengaruhi hasil belajar terdiri dari faktor intern dan faktor ekstern. Faktor intern ada dalam diri siswa meliputi faktor jasmani, psikologi siswa dan kelelahan, sedangkan faktor ekstern meliputi segala sesuatu dari luar diri siswa atau faktor lingkungan.

\section{Penilaian Hasil Belajar}


Penilaian hasil belajar dalam Kurikulum Tingkat Satuan Pendidikan dapat dilakukan dengan penilaian kelas, tes kemampuan dasar, penilaian akhir satuan pendidikan dan sertifikasi, beachmarking, dan penilaian program (Mulyasa, 2006: 258). Maka dalam penelitian ini, akan menggunakan penelitian kelas yang dilakukan dengan ulangan harian. Mulyasa (2006: 259), menyatakan bahwa ulangan harian dilakukan setiap proses pembelajaran dalam kompetensi tertentu. Ulangan harian ini terdiri dari seperangkat soal yang harus dijawab oleh peserta didik, dan tugas-tugas terstruktur yang berkaitan dengan konsep yang dibahas.

\section{E. Model Siklus Belajar}

Siklus Belajar merupakan salah satu model pembelajaran yang berlandaskan pada pandangan konstruktivisme. Pandangan ini berasumsi bahwa mengajar bukan sebagai proses dimana gagasan-gagasan guru diteruskan pada para siswa, melainkan sebagai proses untuk mengubah dan membangun gagasan-gagasan siswa yang sudah ada. Menurut Prasetyo (2004: 5.8) Siklus Belajar adalah suatu model pembelajaran yang fleksibel, terutama bagi seseorang yang kurang mendapat pengalaman langsung, sehingga melalui Siklus Belajar siswa akan memperoleh pengalaman tersebut. Menurut Renner \& Abraham (Yulianti, 2004:3) Siklus Belajar dikembangkan pertama kali oleh Karplus, yang tergabung dalam Science Curriculum Improvement Study (SCIS). Pada awalnya Karplus dan Their memberi istilah fase-fase dalam Siklus Belajar dengan nama fase eksploration, invention, dan discovery. Lawson ( Prasetyo, 2004: 5.3) memberi nama fase-fase tersebut dengan istilah eksploration (eksplorasi), term introduction (pengenalan istilah), dan concept application (aplikasi konsep).

\section{Fase Eksplorasi}

Pada fase ini guru menyajikan fakta atau fenomena yang berkaitan dengan konsep yang akan diajarkan. Siswa menyelidiki fenomena tersebut dengan bimbingan minimal sehingga menimbulkan pertanyaan-pertanyaan atau kekomplekan yang tidak dapat mereka pecahkan dengan pola penalaran yang biasa mereka lakukan. Fase ini menyediakan kesempatan bagi siswa untuk menggunakan pengetahuan awalnyadalam mengobservasi, memahami, serta mengkomunikasikannya pada orang lain berdasarkan konsep-konsep yang telah mereka ketahui. Tujuan dari kegiatan ini adalah untuk melibatkan siswa secara aktif dalam suatu aktivitas yang dapat menumbuhkan rasa ingin tahu dan motivasi belajar. Disamping itu kegiatan pada fase ini memungkinkan siswa menyadari konsep yang telah dimilikinya.

\section{Fase Pengenalan Istilah}


Pada fase ini siswa menyampaikan gagasan-gagasan kemudian mendiskusikannya dalam konteks apa yang telah diamati selama fase eksplorasi. Guru memberikan penguatan terhadap jawaban atau gagasan yang diungkapkan siswa, mengenalkan istilah-istilah dan penjelasan, pengkontrasan, mengusulkan alternatif pemecahan, atau memperbaiki miskonsepsi siswa. Siswa dengan bimbingan guru mengorganisasikan datanya untuk menemukan keteraturan atau hubungan antar konsep.

\section{Fase Aplikasi Konsep}

Fase ini memberikan kesempatan bagi siswa untuk menggunakan konsep-konsep yang telah diberikan pada fase pertama dan kedua untuk menyelesaikan persoalan dalam konteks yang berbeda. Siswa menerapkan konsep yang telah mereka dapat pada situasi baru, baik untuk memahami sifat-sifat konsep lebih jauh (materi pengayaan) atau dalam konteks kehidupan sehari-hari. Guru membantu menginterpretasi dan menggeneralisasi hasil pengalaman siswa. Siswa memperoleh penguatan dan pengembangan struktur mental yang baru.

Menurut Dalhar (Yulianti, 2004:4) fase ini memberikan kontribusi yang cukup penting dalam proses belajar, sebab biasanya informasi itu dinilai kurang berharga jika tidak dapat diterapkan di luar konteks di mana informasi itu dipelajari. Jadi generalisasi atau transfer informasi pada situasi-situasi baru merupakan fase kritis dalam belajar. Selain itu fase ini dapat juga dikatakan sebagai umpan balik. Fase ini juga merupakan evaluasi apakah pembelajaran dapat diterima atau tidak oleh siswa. Proses belajar belum terjadi, jika siswa tidak bisa menerapkan atau menggunakan apa yang telah ia pelajari. Jika ia belajar suatu aturan, maka ia akan dapat menerapkan aturan tersebut dalam penyelesaian masalah lain. Jika ia belajar suatu fakta, maka ia akan dapat mengakui fakta tersebut.

Siklus Belajar terdiri dari tiga fase yaitu eksplorasi, pengenalan istilah, dan aplikasi konsep. Eksplorasi memberi kesempatan pada siswa untuk menemukan pola, pengenalan istilah memberi kesempatan guru untuk memperkenalkan istilah dan memberi kesempatan kepada siswa untuk memadukan pola serta istilah yang kemudian dipakai untuk membentuk konsep. Akhirnya, aplikasi konsep dan istilah membawa siswa untuk menemukan penerapanpenerapan (dan yang tidak dapat diterapkan) suatu konsep dalam konteks yang baru.

Eksplorasi, pengenalan istilah, dan aplikasi konsep selalu berada dalam bentuk spiral. Bila Siklus Belajar, digunakan untuk menyusun kurikulum, kurikulum tersebut membentuk spiral, sebab istilah-istilah dan konsep yang dipelajari sebelumnya selalu diterapkan dalam Siklus Belajar berikutnya. Siklus Belajar terdiri dari tiga fase yaitu eksplorasi, pengenalan istilah, dan aplikasi konsep. Eksplorasi memberi kesempatan pada siswa untuk menemukan 
pola, pengenalan istilah memberi kesempatan guru untuk memperkenalkan istilah dan memberi kesempatan kepada siswa untuk memadukan pola serta istilah yang kemudian dipakai untuk membentuk konsep. Akhirnya, aplikasi konsep dan istilah membawa siswa untuk menemukan penerapan-penerapan (dan yang tidak dapat diterapkan) suatu konsep dalam konteks yang baru. Berikut gambar sifat Siklus Belajar menurut Lawson (Prasetyo:2004:5.6).

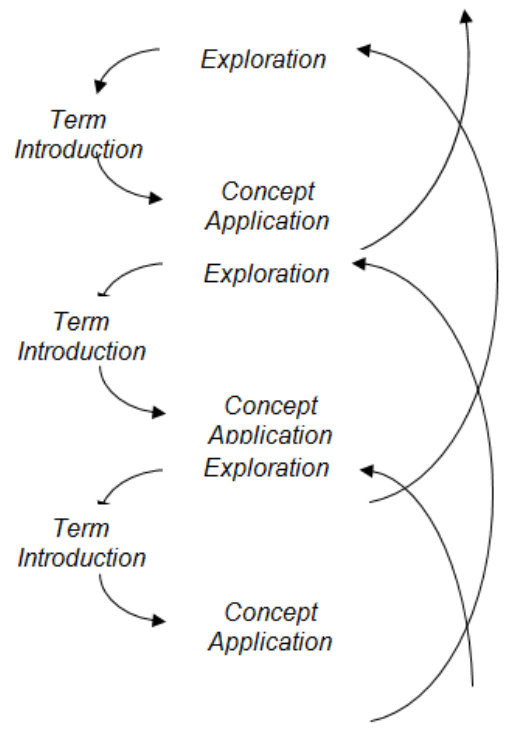

Gambar 1. Sifat Siklus Belajar menurut Lawson (Prasetyo, 2004:5.6)

Eksplorasi, pengenalan 1stılah, dan aplıkası konsep selalu berada dalam bentuk spiral, seperti gambar 1. Bila siklus belajar digunakan untuk menyusun kurikulum, kurikulum tersebut membentuk spiral, sebab istilah-istilah dan konsep yang dipelajari sebelumnya selalu diterapkan dalam siklus belajar berikutnya.

Dalam pelaksanaannya, Siklus Belajar memiliki kelebihan dan kekurangan. Kelebihan dan Kekurangan Siklus Belajar tersebut adalah:

1. Kelebihan Siklus Belajar (http://www.scribd.com/doc/16315603/Model-Siklus-Belajar diakses tanggal 5 Maret 2013 pukul 15.00). Ditinjau dari dimensi peserta didik, penerapan strategi ini memberi keuntungan sebagai berikut:

a. Meningkatkan motivasi belajar karena peserta didik dilibatkan secara aktif dalam proses pembelajaran.

b. Membantu mengembangkan sikap ilmiah peserta didik.

c. Pembelajaran menjadi lebih bermakna.

2. Kelemahan Siklus Belajar (http://www.scribd.com/doc/16315603/Model-Siklus-Belajar diakses tanggal 5 Maret 2013 pukul 15.00) adalah:

a. Efektifitas pembelajaran rendah jika guru kurang menguasai materi dan langkahlangkah pembelajaran. 
b. Menuntut kesungguhan dan kreativitas guru dalam merancang dan melaksanakan proses pembelajaran.

c. Memerlukan pengelolaan kelas yang lebih terencana dan terorganisasi.

d. Memerlukan waktu dan tenaga yang lebih banyak dalam menyusun rencana dan melaksanakan pembelajaran.

Agar tujuan pembelajaran tercapai, kegiatan-kegiatan dalam setiap fase-fase harus dirangkai dengan baik. Kompetensi yang bersifat psikomotorik dan afektif misalnya akan lebih efektif bila dikuasai melalui kegiatan semacam praktikum, lingkungan belajar yang perlu diupayakan agar Siklus Belajar berlangsung konstruktivistik adalah:

1. Tersedianya pengalaman belajar yang berkaitan dengan pengetahuan yang telah dimiliki siswa.

2. Tersedianya berbagai alternatif pengalaman belajar jika memungkinkan.

3. Terjadinya transmisi sosial, yakni interaksi dan kerja sama individu dengan lingkungan.

4. Tersedianya media pembelajaran.

5. Kaitan konsep yang dipelajari dengan fenomena sedemikian rupa sehingga siswa terlibat secara emosional dan sosial yang menjadikan pembelajaran berlangsung menarik dan menyenangkan.

Berdasarkan penjelasan di atas dapat ditarik kesimpulan bahwa model Siklus Belajar adalah suatu model pembelajaran dimana siswa mendapatkan pengalaman langsung dalam kegiatan pembelajaran melalui tahap eksplorasi, pengenalan istilah, dan aplikasi konsep.

\section{METODE PENELITIAN}

\section{A. Jenis Penelitian}

Jenis Penelitian yang akan dilakukan yaitu Penelitian Tindakan Kelas atau Classroom Action Research (CAR). Dalam Penelitian Tindakan Kelas (PTK) ini, penelitian dilakukan oleh guru itu sendiri dengan tujuan memperbaiki pembelajaran, sehingga hasil belajar siswa dapat meningkat. Guru sebagai pengelola program di kelas merupakan sosok yang benarbenar mengenal lapangan tempat dia mengajar. Oleh karena itu, guru kelas inilah yang mengetahui dan mengenal situasi kelasnya termasuk masalah yang ada di dalamnya. Guru dituntut untuk melakukan tindakan-tindakan untuk melakukan perubahan-perubahan yang berkenaan dengan upaya menuju perbaikan. 


\section{B. Obyek Penelitian}

Obyek penelitian ini adalah hasil belajar Pkn siswa kelas VIIA SMP Negeri 3 Bantul melalui model Siklus Belajar pada materi Perlindungan dan Penegakan Hak Asasi Manusia di Indonesia.

\section{Subjek Penelitian}

Subjek penelitian ini adalah guru dan siswa kelas VIIA SMP Negeri 3 Bantul yang berjumlah 32 siswa. Subyek diambil berdasarkan pertimbangan guru kelas VIIA sebagai guru kelas. Pengamatan dilakukan oleh satu orang guru teman sejawat yaitu guru kelas VIIA yang sudah dilatih.

D. Tempat dan waktu penelitian

Penelitian Tindakan Kelas ini dilaksanakan di kelas VIIA SMP Negeri 3 Bantul yang beralamat di Peni kelurahan Palbapang Kecamatan Bantul Kabupaten Bantul. Penelitian ini dilaksanakan selama 4 bulan, dimulai bulan Maret 2013 sampai dengan Juni 2013.

E. Instrumen Penelitian

Instrumen dalam penelitian adalah alat yang digunakan oleh peneliti dalam pengumpulan data agar pekerjaannya lebih mudah dan lebih baik (Arikunto, 2007: 80). Instrumen yang digunakan dalam penelitian ini adalah sebagai berikut:

1. Tes

Tes adalah serentetan pertanyaan atau latihan atau alat lain yang digunakan untuk mengukur keterampilan, pengetahuan, intelegensi, kemampuan atau bakat yang dimiliki oleh individu atau kelompok (Arikunto, 2009: 32). Tes digunakan untuk mengukur hasil belajar siswa pada ranah kognitif. Hasil belajar pada ranah kognitif berdasarkan taksonomi Bloom meliputi jenjang hafalan (C1), pemahaman (C2), penerapan (C3), analisis (C4), sintesis (C5), dan evaluasi (C6). Pada penelitian ini, aspek kognitif yang diukur dibatasi hanya pada aspek hafalan $(\mathrm{C} 1)$, pemahaman $(\mathrm{C} 2)$, dan penerapan (C3). Tes yang digunakan adalah tes tertulis dalam bentuk pilihan ganda yang disusun berdasarkan indikator sesuai Kurikulum Tingkat Satuan Pendidikan (KTSP). Tes diberikan sebelum awal tindakan (pre test) dan di akhir tindakan (post test). Langkah-langkah penyusunan instrumen hasil belajar ranah kognitif adalah sebagai berikut:

a. Mengidentifikasi tujuan-tujuan pembelajaran dan lingkup bahan ajar yang semestinya diungkap.

b. Membuat soal.

c. Membuat kunci jawaban dan penskoran. 
Hasil pre test tersebut digunakan untuk membandingkan dengan hasil post test siswa, sehingga akan terlihat apakah model Siklus Belajar yang dilakukan terbukti berhasil atau tidak dalam meningkatkan hasil belajar PKn pada siswa kelas VIIA SMP Negeri 3 Bantul.

\section{Lembar Observasi}

Observasi dilaksanakan selama proses pembelajaran berlangsung dengan menggunakan lembar observasi terlampir. Observasi dilakukan untuk melihat secara langsung bagaimana partisipasi siswa pada saat proses pembelajaran berlangsung. Hasil pengamatan tersebut kemudian akan menjadi nilai untuk ranah afektif dan psikomotor.

\section{PEMBAHASAN}

Hasil evaluasi pada tahap pra tindakan menunjukkan bahwa hasil belajar PKn siswa kelas VIIA masih rendah. Hal ini ditunjukkan dengan nilai rata-rata siswa sebesar 64,97, sedang persentase siswa yang mencapai KKM 70 baru sebesar 56,25\% atau sebanyak 18 anak. Hasil belajar PKn yang masih rendah ini disebabkan oleh kegiatan pembelajaran yang masih didominasi oleh guru, sehingga tujuan pembelajaran PKn seperti yang diharapkan belum bisa tercapai secara optimal. Guru mengajar dengan metode ceramah sehingga siswa kurang berpartisipasi aktif dalam kegiatan pembelajaran. Pada saat mengajarkan materi hakekat HAM siswa mendengarkan penjelasan guru, mencatat materi, dan melakukan tanya jawab. Kegiatan pembelajaran dengan metode seperti ini mengakibatkan siswa kurang memahami apa yang disampaikan oleh guru sehingga berpengaruh terhadap hasil belajar. Hal ini sesuai dengan pernyataan Arief (2002:139-140) yang menyatakan bahwa kelemahan metode ceramah adalah siswa kurang menangkap apa yang disampaikan oleh guru dan terjadinya verbalisme.

Hasil belajar PKn siswa siklus I mengalami peningkatan apabila dibanding pra tindakan setelah penerapan model Siklus Belajar. Model Siklus Belajar yang diterapkan dalam kegiatan pembelajaran ini sesuai dengan model Siklus Belajar yang dikembangkan Lawson, yaitu terdiri dari fase eksplorasi, pengenalan istilah, dan aplikasi konsep (Prasetyo, 2004: 5.3). Model Siklus Belajar ini dipilih karena mampu melibatkan siswa secara aktif dalam kegiatan pembelajaran dan memungkinkan siswa untuk mendapatkan pengalaman langsung dalam kegiatan pembelajaran. Pada fase eksplorasi siklus I, siswa memulai pembelajaran dengan melakukan kegiatan diskusi kelompok mengenai dasar hukum adanya HAM dan lembaga hukum yang menaunginya. Dalam fase ini, siswa melakukan diskusi kelompok sesuai dengan 
langkah-langkah yang ada dalam lembar kerja siswa. Siswa melakukan diskusi kelompok mengenai materi dasar hukum adanya HAM dan undang-undang atau pasal yang menanganinya melalui kelompok-kelompok belajar. Tujuan dari kegiatan ini adalah untuk melibatkan siswa secara aktif dalam suatu aktivitas yang dapat menumbuhkan rasa ingin tahu dan motivasi belajar.

Langkah selanjutnya setelah kegiatan diskusi kelompok adalah guru mengenalkan istilah-istilah yang berkaitan dengan materi yang sedang dipelajari. Guru menggunakan metode ceramah untuk menjelaskan istilah-istilah yang berhubungan dengan dasar hukum adanya HAM dan kelembagaannya, misalnya tentang UUD 1945 pasal 28A sampai pasal 28J serta UU. No.39 Tahun 1999. Dalam fase pengenalan istilah ini, siswa mendengarkan dan mencatat hal-hal yang disampaikan oleh guru.

Dalam fase aplikasi konsep, guru memberikan permasalahan atau fenomena yang terjadi dalam kehidupan sehari-hari secara lisan kepada siswa. Permasalahan tersebut diantaranya dasar hukum adanya HAM dan lembaga yang menaunginya, dan lain-lain. Siswa menjawab pertanyaan tersebut secara lisan atau tertulis kemudian siswa dan guru membahas permasalahan atau fenomena tersebut bersama-sama.

Model Siklus Belajar yang dikembangkan pada siklus I ini terbukti dapat meningkatkan hasil belajar PKn siswa. Hal ini sesuai dengan pernyataan yang disampaikan Yulianti (2004:18) yang mengatakan bahwa Siklus Belajar dapat meningkatkan motivasi dan hasil belajar karena peserta didik dilibatkan secara aktif dalam proses pembelajaran. Hasil belajar PKn yang diperoleh siswa pada siklus I menunjukkan hasil yang meningkat dengan nilai ratarata 71,03 dari nilai rata-rata 64,97 pada pra tindakan. Sementara persentase siswa yang telah mencapai KKM 70 pada siklus I meningkat menjadi $61,80 \%$ dari $56,25 \%$ pada saat pra tindakan. Pada siklus I sebanyak 21 siswa sudah mencapai KKM dan 11 siswa belum mencapai KKM 70. Persentase ketuntasan siswa pada siklus I baru mencapai 61,80\%. Untuk itu penelitian dilanjutkan ke siklus II dengan melihat catatan-catatan penting yang masih perlu direfleksikan lagi untuk pembelajaran berikutnya.

Pelaksanaan tindakan siklus II merupakan tindak lanjut dari siklus I. Pada siklus I ditemukan faktor penyebab kurang tercapainya indikator keberhasilan untuk ranah kognitif, antara lain terjadinya kekurang efektifan pada fase eksplorasi, penyampaian istilah yang kurang menarik dan cenderung monoton, dan guru yang tidak menghadirkan situasi yang nyata dalam kegiatan aplikasi konsep. Tindakan perbaikan yang dilakukan guru pada siklus II mencakup tindakan-tindakan pada fase eksplorasi, pengenalan istilah dan aplikasi konsep. 
Pada fase eksplorasi, guru melakukan tindakan-tindakan perbaikan berupa pembentukan pengurus dalam kelompok dan penambahan jumlah media pembelajaran yang digunakan dalam diskusi kelompok. Kegiatan eksplorasi pada siklus II ini mencakup kegiatan diskusi kelompok mengenai materi menganalisis kasus-kasus pelanggaran HAM di Indonesia, di lingkungan sekolah, dan dimasyarakat. Pembagian tugas dalam kegiatan diskusi kelompok diatur oleh ketua kelompok. Setiap kelompok juga dapat langsung melaksanakan kegiatan diskusi kelompok tanpa harus menunggu giliran karena jumlah buku referensi yang mencukupi, sehingga kegiatan pada fase eksplorasi ini dapat berjalan dengan efektif.

Tindakan perbaikan juga dilakukan oleh guru pada fase pengenalan istilah. Guru menggunakan media slide power point untuk membantu menjelaskan materi dalam fase pengenalan istilah. Materi-materi penting dapat divisualisasikan dengan menarik dan dijelaskan guru secara lisan sehingga siswa lebih memahami materi yang disampaikan guru. Pada siklus II ini, guru menjelaskan istilah-istilah yang berkaitan dengan kasus pelanggaran HAM yang terjadi di Indonesia misalnya tentang pengertian Genosida yaitu pembantaian etnis antara etnis dayak dengan etnis Madura, tindakan main hakim sendiri dan lain-lain. Penggunaan media slide power point ini dirasa sangat efektif untuk membantu siswa memahami materi-materi yang dipelajari. Arief (2002:79) menyampaikan bahwa pemilihan media pembelajaran yang tepat menempati posisi yang cukup penting sebagai salah satu komponen sistem pembelajaran. Tanpa media pembelajaran yang tepat, komunikasi tidak akan terjadi dan proses pembelajaran sebagai proses komunikasi juga tidak akan bisa berlangsung secara optimal. Media pembelajaran adalah komponen integral dari sistem pembelajaran.

Pada fase aplikasi konsep, guru menghadirkan situasi nyata dalam kegiatan pembelajaran yaitu dengan menghadirkan dokumen atau gambar kasus-kasus pelanggaran yang terjadi di Indonesia berupa Media Cetak/elektronik. Guru memberikan permasalahan kasus pelanggaran dan upaya penegakannya. Siswa memberikan jawaban dan menjelaskan permasalahan yang disampaikan guru di depan kelas.

Upaya perbaikan model Siklus Belajar pada siklus II terbukti dapat meningkatkan hasil belajar PKn siswa. Hal ini sesuai dengan pernyataan yang disampaikan Yulianti (2004:18) yang mengatakan bahwa Siklus Belajar dapat meningkatkan motivasi dan hasil belajar karena peserta didik dilibatkan secara aktif dalam proses pembelajaran. Pada siklus II hasil pembelajaran PKn meningkat jika dibandingkan dengan siklus I. Hal ini ditunjukkan oleh peningkatan nilai rata-rata kelas dari 71,03 menjadi 75,80 . Persentase siswa yang telah mencapai KKM 70 pada siklus II juga meningkat menjadi $75 \%$ atau sebanyak 24 siswa. Data 
yang dihasilkan pada siklus II ternyata sudah memenuhi kriteria keberhasilan penelitian, sehingga penelitian tidak perlu dilanjutkan ke siklus berikutnya. Peningkatan hasil belajar tersebut menggambarkan bahwa model pembelajaran Siklus Belajar dapat meningkatkan hasil belajar PKn siswa kelas VIIA SMP 3 N Bantul.

\section{SIMPULAN DAN SARAN}

A. Simpulan

Berdasarkan hasil penelitian dan pembahasan pada bab sebelumnya, dapat disimpulkan hal-hal sebagai berikut:

1. Pada tahap pra tindakan, menunjukkan bahwa hasil belajar PKN siswa kelas VIIA masih rendah. Nilai rata-rata kelas baru mencapai 64,97 sedangkan persentase siswa yang mencapai KKM 70 baru mencapai 56,25\%.

2. Pada siklus I, guru menggunakan model Siklus Belajar dalam kegiatan pembelajaran PKn. Model Siklus Belajar yang digunakan guru mengacu pada model Siklus Belajar yang dikembangkan oleh Lawson yang terdiri dari tiga fase, yaitu fase eksplorasi, pengenalan istilah, dan aplikasi konsep. Penerapan model Siklus Belajar pada siklus I dapat meningkatkan hasil belajar PKn siswa. Hal ini ditunjukkan dengan nilai rata-rata kelas yang meningkat menjadi 71,03 dan sementara persentase siswa yang mencapai KKM 70 juga meningkat menjadi $61,80 \%$.

3. Pada siklus II, guru melakukan perbaikan pembelajaran model Siklus Belajar pada fase eksplorasi, pengenalan istilah, dan aplikasi konsep. Pada fase eksplorasi, guru melakukan perbaikan tindakan berupa penunjukkan pengurus dalam kelompok sehingga pembagian tugas lebih merata dan keaktifan siswa dapat meningkat. Selain itu, guru juga menambah jumlah media pembelajaran yang digunakan untuk melakukan percobaan. Pada fase pengenalan istilah, guru melakukan perbaikan tindakan dengan menggunakan media slide power point untuk menjelaskan istilah-istilah yang berhubungan dengan materi yang sedang dipelajari. Sedang pada fase aplikasi konsep, guru melakukan perbaikan dengan menghadirkan situasi nyata dalam kegiatan pembelajaran, tidak sekedar memberikan permasalahan secara lisan. Adanya perbaikan-perbaikan pada siklus II, dapat meningkatkan hasil belajar PKn siswa kelas VIIA SMP Negeri 3 Bantul. Nilai rata-rata siswa meningkat menjadi 75,80 dan persentase siswa yang mencapai KKM 70 meningkat menjadi $75 \%$. 
B. Saran

Berdasarkan hasil penelitian dan pembahasan di atas, disarankan hal-hal sebagai berikut:

1. Bagi siswa, hasil belajar yang sudah baik harus dipertahankan dan hendaknya siswa lebih aktif dalam mengikuti pelajaran PKn.

2. Bagi guru, hendaknya menjadikan model Siklus Belajar sebagai model pembelajaran dalam melaksanakan pembelajaran PKn, sehingga siswa lebih aktif dalam kegiatan pembelajaran dan dapat meningkatkan hasil belajar PKn mereka.

3. Bagi sekolah, pada umumnya guru kelas banyak yang belum mengetahui tentang model Siklus Belajar, sehingga masih belum diterapkan dalam pembelajaran. Sebaiknya sekolah mengadakan pelatihan terhadap guru-guru kelas mengenai model-model pembelajaran khususnya model Siklus Belajar dengan mengundang pakar yang ahli dibidangnya.

4. Bagi peneliti lain, peneliti lain yang tertarik untuk melakukan penelitian dengan menggunakan model Siklus Belajar, diharapkan dapat melakukan penelitian lebih lanjut tentang aspek-aspek lain dalam pembelajaran PKn dengan menggunakan model Siklus Belajar dan dapat mengaplikasikannya pada pokok bahasan atau materi yang berbeda.

\section{DAFTAR PUSTAKA}

Depdiknas. 2008. Peraturan Menteri Pendidikan Nasional Nomor 26 Tahun 2006 tentang Standar Isi untuk Satuan Pendidikan Dasar dan Menengah. Jakarta: Depdiknas

http://www.scribd.com/doc/16315603/Model-Siklus-Belajar di akses tanggal 5 Maret 2013 pukul 15.00 WIB

Kasbolah, Kasihani E. S. 1999. Penelitian Tindakan Kelas. Jakarta: Depdikbud

Kusumah, W. \& Dwitagama, D. 2010. Mengenal Penelitian Tindakan Kelas. Jakarta: Indeks

Moedjiono \& Dimyati, Moh. 1993. Strategi Belajar Mengajar. Jakarta: Depdikbud

Mulyasa, E (2006) Menjadi Guru Profesional Menciptakan Pembelajaran yang Kreatif dan menyenangkan. Bandung: Remaja Rosdakarya

Ngalim Purwanto. (1991). Psikologi Pendidikan . Bandung: Rosdakarya.

Oemar Hamalik (2005). Metode Belajar dan Kesulitan-Kesulitan Belajar. Bandung: Tarsito

Oemar Hamalik.(2006). Proses Belajar Mengajar. Bandung: Remaja Rosdakarya

Prasetyo, Zuhdan K. 2004. Kapita Selekta Pembelajaran Fisika. Yogyakarta: Pusat Penerbitan Universitas Terbuka. 
Rusman. (2011). Model-Model Pembelajaran Mengembangkan Profesionalisme `Guru. Jakarta: Rajawali Pers.

Slameto. (2003). Belajar dan Faktor-faktor yang mempengaruhinya. Jakarta: Rineka Cipta.

Suharsimi Arikunto. 1991. Dasar-Dasar Evaluasi Pendidikan. Yogyakarta: Lembaga Penelitian UNY . 2002. Prosedur Penelitian Suatu Pendekatan Praktik. Jakarta: Rineka Cipta. . 2009. Dasar-dasar Evaluasi Pendidikan. Jakarta: Rineka Cipta.

Yulianti, K. (2004). Penerapan Model Siklus Belajar (Learning Cycle) pada Pembelajaran Barisan dan Deret dalam Upaya Meningkatkan Koneksi Matematik Siswa. Skripsi UPI. Bandung: Tidak Diterbitkan 